\title{
BRITISH POST OFFICE AND TELECOMMUNICATIONS SERVICES
}

\begin{abstract}
T a debate on the Post Office in the House of 1 Commons on March 28, the Postmaster-General, Mr. R. Bevins, said that out of capital expenditure of $£ 132$ million during 1962-63, Britain will spend about $£ 122$ million on telecommunications, or 11 per cent more than in the present year, partly in modernizing the system as new techniques developed, by automatization through the development of subscribers' trunk dialling, by now international cables and, in the long term, by satellites, and partly in reducing the waiting list. Inland trunk traffic is growing at the rate of about 12 per cent a year, and by the end of next year there will be about 37,000 trunk circuits as against 24,000 three years ago. It is planned to make subscriber trunk dialling available to about 90 per cent of subseribers by 1970 , and it is estimated that savings to subscribers during 1962-63 on the same number of calls as with the old tariff will be $£ 7$ million. The waiting list has been reduced in six years from 250,000 to 53,000 . Later this year Britain will be opening the first electronic exchange in Europe to carry public telephone calls. Present techniques, said Mr. Bevins, limited to about 100 the number of telephone systems which can be carried by long-distance submarine cables, but a cable in the design stage might increase this to about 250. Traffic demands in ten or twenty years time are likely to justify the high cost of communication satellites, which can probably offer 1,000 simultaneous telephone calls and perhaps a television channel. He hoped that the Commonwealth will play its part in this, and he had welcomed representatives from all Commonwealth countries who had come to consider Commonwealth policy. Britain
\end{abstract}

is also co-operating with the Americas in test transmissions through satellites, but we may be many years away from a full, universally operated system.

In the debate, Mr. P. Holland asked for some information on the experiments in automation being conducted at Luton and Norwich, but this point was not covered in a full reply on the debate by the Assistant Postmaster-General, Miss M. Pike, who, however, instanced the new telephone exchange at Altrincham and the head post office at Hitchin as illustrating the possibilities of introducing new ideas and techniques into post office buildings. Both buildings were designed by a special research team, a joint enterprise with the Ministry of Works. A large-scale experiment covering parcel post for the whole of East Anglia is planned to start this year, and the Post Office is experimenting with the sorting and segregation of mail as well as with the sorting of parcels. Demand for telex has doubled in the past four years, and 1,600 new lines during 1962-63 will bring the total to more than 10,000. About 20,000 subscribers are expected by 1970, and to cope with this growth 21 new telex exchanges will be required; work on six will be started during 1962-63. Referring to the Post Office's increasing concern with the transmission of data and the use of telecommunications networks, Miss Pike stressed the need for ensuring a background of submarine communications throughout the Commonwealth. Despite its huge effort in developing satellite communications, the American Telephone and Telegraph Company has decided not to change its large investment in plans in submarine cables between now and 1965-66.

\section{PREPARATION OF SCIENTIFIC REPORTS AND BOOKS}

\begin{abstract}
THE theme of this year's conference of the Scottish Branch of Aslib (Association of Special Libraries and Information Bureaux) was the writing, editing, publishing, binding and storage of the technical report. The meeting was of a historic nature as it was the first two-day residential course which the Scottish Branch has held. To enable as many as possible to attend, it was held in Perth, once the capital of Scotland and a point easily reached from all parts of the country. The meeting was accorded a civic reception from the Lord Provost of Perth, Mr. John T. Young, and the magistrates.

The first speaker was Dr. Archie Clow, producerin-charge, Science Unit of the British Broadcasting Corporation, who spoke on "Communication in Science". Dr. Clow said that his experience over the past ten years was that interest in science in the public as a whole is very high. Dr. Clow spoke on the need for careful writing and editing of a broadcast science talk pointing out that the speaker had to do everything possible to maintain the flow of thought. The listener could not stop the speaker and ask for explanations or, as in reading, turn back the pages. In one aspect broadcasting did not differ from other forms of communication and that was intelligibility
\end{abstract}

in the sense of what the listener could recall an hour or a week later. He agreed that there was a great need to present the hard dry bones of scientific investigations with imagination.

The second paper was "The Editorial Function", which was given by Mr. G. N. J. Beck, assistant editor of Endeavour, who is principally concerned with the production of the foreign-language editions of that journal. He spoke on the choice of the subject of articles and their commissioning from suitable authors. He outlined how the flow of material was kept going between the editorial offices and the printers of the foreign issues. Pointing out that they used the services of translators belonging to the countries covered, he indicated the occasional difficulties that arose in translation of an idiomatic phrase comprehensible to the original author but of which a literal translation would mean nothing. $\mathrm{He}$ also emphasized the need for clear and intelligent writing and proof reading.

Mr. D. Ainslie Thin, director of Messrs. Oliver and Boyd, Ltd., followed with a talk on "Publishing Scientific and Technical Material". Mr. Thin dealt with scientific material from the publishers' point of view. He spoke of author's royalties and the need 
for modern attractive book jackets. He also referred to the vexed subject of indexes, which was later a matter for discussion from the floor. It was a question of whether or not it was better for the author or a trained indexer to do this work. Mr. Thin went into detail on the various stages in the publication of a book, the necessity for a clcar layout, illustrations to match the text, type faces to be used and so on. It was suggested to him that it would be useful if publishers were to print the bibliographical detail on the flyleaf and to indicate the font-type used. The first of these suggestions he thought to be a useful one, but doubted if it would be practical to elaborate on the type as in some books several fonts were used. Mr. Thin also went into the question of the age of books and stocks. One suggestion from the floor was that when a publisher saw his stock of a particular book running low he should consider the advisability of making a microfilm of it. He again spoke of the difficulty met in the publication of a translated version of a book. It was sometimes difficult to get the translator and the author to agree on the final version to be issued.

At the end of the first day there was some time given for discussion. In addition to the items already mentioned the question of the use of microfilm was also raised. It apparently is still not quite acceptable to the average scientist, who prefers paper in his hands. There was also some discussion on the need and methods for getting information over to the working man at the factory bench. Dr. Clow had found there was interest expressed in the broadcasts, but it was essential that the correct speaker was employed to present the matter in an interesting way.

The second day of the conference opened with a talk by Mr. David Moncur, manager, Dunn and Wilson's, Falkirk. Mr. Moncur, who illustrated his talk with a series of transparencies, went into elaborate detail of the process of binding books and periodicals in Britain. He spoke of a recent visit to the United States where the process of binding had been streamlined but had poor effect. One library ho spoke of had all its books bound in one colour, which was extremely monotonous to the eye. In Britain much is done to vary the colour. Mr. Moneur also spoke of the new trends in binding by the use of plastic sleeves and front boards.

The final paper of the day and of the conference was given by Dr. D. J. Urquhart, director of the National Lending Library at Boston Spa. He dealt with the availability and translation of foreign publications. He spoke on the building up of the National Lending Library and its endeavour to provide a 48 -hr. service to borrowers. He pointed out that the person who worked in a sizeable research organization and perhaps had access to big libraries was better off than he who worked in a small industry remote from technical college and university libraries. He thought that the public libraries had a great responsibility to increase their guides to scientific literature, supplying the basic reference tools and using the resources available to them through Boston Spa. Reference was also made to tho Russian translations held at Boston Spa and how they were available to borrowers.

\section{THE EAST AFRICAN VIRUS RESEARCH INSTITUTE}

$\mathrm{I}_{\mathrm{F}}^{\mathrm{N}}$ his annual report*, the acting director of the East African Virus Research Institute, Dr. J. D. Gillett, explains that the middle of Africa is the home of many different virus diseases, particularly those which are transmitted to man by mosquitoes. It is not enough merely to study virus, vector and vertebrate host, including man, as separate entities. These, their predators and parasites, their associated plants and, indeed, the whole community of living things must be considered, together with the physical environment, as a single interacting system. It is only thus that one can begin to understand the nature of the complex factors which play a part in the maintenance of virus populations, and of the variations in these factors which lead to the infection of man from wild animals and bird hosts, or to the sudden occurrence of human epidemics. It is only by such a broad approach that explanations will be found for 'epidemic years'. While the paucity of technical facilities for virus research in Africa is well known, the richness in natural facilities is unsurpassed anywhere.

The approach to virus research in Africa must be mainly ecological. If, however, it is to avoid the danger of becoming merely descriptive, field observation must be supported by laboratory experiments whenever possible. Laboratory studies, if properly planned, can produce short-cut answers and suggest

* East Africa High Commission. East African Virus Research Institute Report, July 1960-June 1961. Pp. ii +56, (Entebbe: Fast African Institute for Medical Researeh,) Sh. 9. valuable clues to complex problems of behaviour. It would be difficult to find a better place for this complementary approach to virus studies. New viruses are being discovered every year. Ten years ago these were mostly being recovered from wild populations of mosquitoes, and their importance to man was largely unknown. With the development of new techniques, however, emphasis has swung more and more to the human patients themselves as a source of new viruses, and now the Institution is in a position to find the cause of many fevers which previously would have been accepted as pyrexias of unknown origin. Many new viruses and virus strains are being discovered. Most of the fevers associated with these newly discovered viruses are relatively mild, or their unpleasant symptoms pass off without permanent after-effects. Apart from individual discomfort, their main importance would appear to be the economic loss to the country concerned that must accompany wholesale absence from work.

The most dramatic of these new virus infections has been the huge epidemic of o'nyong-nyong. This appears to have begun in Uganda in 1959, moved steadily forward in a south-casterly direction for about a year and then, coming up against natural ecological barriers to spread farther in that direction, halted before breaking out in separate foci many hundreds of miles apart. The line of the initial advance depended on almost continuous permanent concentrations of the main vector, the malaria mosquito, 